\title{
14 \\ The future of strategic studies: The next golden age
}

\author{
Robert O'Neill
}

It was stimulating to receive the organisers' challenge to discuss the future of strategic studies rather than the past. It is so much easier to be wrong about the future than about the past-and it matters a lot if you are wrong in our profession! Think of all the bad strategic plans that have been hatched by supposedly excellent professionals, such as the Schlieffen Plan, Fall Gelb-the German General Staffs plan for the invasion of France, which was discarded by Hitler due to Manstein's persuasionand Operation Barbarossa, which was not discarded by Hitler but should have been.

Now, maybe it is better to have a bad strategic plan than no plan at all. At least it creates a framework for the design and development of armed forces and focuses the minds of those who might have to implement them on the intelligent use of the forces available to them. Personally, I doubt this-the combination of strategic plans and forces to implement them does create a temptation to use them-such as that which overcame Kim Il-Sung's judgement in 1950 in invading South Korea, or that of the Chinese in going to war against the Vietnamese in 1979, administering what Deng Xiaoping described to President Jimmy Carter as 'a slap to a naughty child'. Strategic plans, if we have them at all, need to be very well 
conceived and controlled at both political and operational levels. And this is where policy research institutes such as the Strategic \& Defence Studies Centre (SDSC) have an important national and international role to play.

I have been invited to forecast the next 'golden age' in strategic studies. This implies that there are non-golden ages in our field, even 'dark ages'. So let me say at the outset that I prefer an output of steady daylight to alternately baking under the golden rays of a midsummer sun and then freezing in wintry darkness. My remarks therefore are aimed at achieving the best performance by our strategic thinkers over most of their working lives. That approach will do more to maintain our societies and our planet intact and at peace than occasional flashes of inspiration born of a terrible time of death and destruction.

What are we aiming at?

\section{Tasks for the 21st century}

So here we are, in the late 2010 s, with many of the dangers of the 21 st century already apparent. Let me run through the most serious of them:

- the proliferation of nuclear weapons

- the development of tough, strongly motivated 'terrorist' forces

- climate change leading to a rise in sea levels and mass movements of displaced persons from low-lying areas

- acute food shortages in badly governed regions, especially in Africa and the Middle East, leading to further waves of distressed people moving into Europe

- accommodation of a more powerful and assertive China

- increasing world population coupled with inadequate quality of government at national, regional and global levels.

They are diverse-much more diverse than planners and thinkers have had to address in previous centuries. Clearly we have a lot to do, and many agencies will have to be involved in developing policies for handling these threats. Military force remains important, but inputs need to be made from most areas of government and expertise outside the realm of government, particularly those of a large university. 


\section{The security policy dialogue in Australia}

Our national record in the past for developing strategic policies has not been a distinguished one. Australia's role until 1942 was essentially that of providing auxiliary forces to Great Britain. We had sketchy plans from the early 1930s but lacked the substantial forces that they required for implementation. The Japanese attacks on Pearl Harbor and Malaya in December 1941 suddenly brought awareness that we are ultimately responsible for our own security. We needed plans plus forces. I recall a conversation in 1974 with General Rowell, who was Deputy Chief of the General Staff in 1941-42. Rowell was asked in January 1942, by a visiting American officer, what he would do if the Japanese landed a force of two divisions on our north-western coast. 'I'd run for the salvage corps,' Rowell replied. It was a flippant response, but it showed that as far as realistic defence plans and actual capabilities were concerned, our cupboard was bare.

In the early 1970s, when I was beginning to write the official history of the Korean War, ${ }^{1}$ I wondered how our plans and policies to address the needs of the Cold War were developed between 1945 and 1950. Rowell walked me through the unrecorded details of our strategic planning for the period 1946-50. The cupboard was still fairly bare, and the size and capacities of our armed forces were low-not to match our plans but to save money. For a while our regular army consisted of two battalions of infantry. Then came the Korean War, and we increased it to three battalions. A national service scheme was developed, but the period of service required was very brief. The navy acquired an aircraft carrier, and the Royal Australian Air Force was upgraded from World War II Mosquitoes to Meteors and then Sabres. We entered into a closer association with Britain in the Australian, New Zealand and Malaya (ANZAM) linkage, and of course we were part of the Australia, New Zealand, United States (ANZUS) Security Treaty, not to mention the Southeast Asia Treaty Organization (SEATO).

Defence planning and strategy rested largely in the hands of the Joint Planning Committee. They, three officers of the rank of colonel or equivalent, reported to the Defence Committee, which was composed of the three chiefs of staff and chaired by the widely feared Secretary of the

1 Robert O'Neill, Australia in the Korean War 1950-53, vol. 1: Strategy and Diplomacy, and vol. 2: Combat Operations, both Australian War Memorial and Australian Government Publishing Service, Canberra, 1981 and 1985, respectively. 
Defence Department, Frederick Shedden. It was interesting for me to trace the origins of policy initiatives from the drafts produced by a major in army headquarters, flowing on to his lieutenant colonel superior, then through the Joint Planning Committee and the Defence Committee to the Cabinet. Sometimes not a lot was changed on the way through. It must have felt good to have been one of those majors on the planning staff in those days.

An important thing to note about our first national defence planning system is that there were few, if any, external inputs. I saw no evidence that anyone inside the defence establishment took any notice of journalists, academics or even diplomats. That last element changed in the mid-1950s as Arthur Tange became Secretary of the Department of External Affairs and joined the Defence Committee as a member in his own right. Tange made contribution with characteristic vigour and cutting power. Soon, as Peter Edwards has related, Tange was complaining that Defence was using External Affairs to do its thinking as well as its own. ${ }^{2}$

Political contributions to the shaping of defence planning were largely confined to the domain of resources-by stating what could be afforded and what could not. I must make an exception here for Percy Spender, who always saw a clear strategic reason for our becoming involved in the Korean War: the gaining of a military alliance with the United States. But this idea did not emerge from his own department nor from the Defence Committee! It was his personal contribution, which not even his prime minister thought achievable when Spender first mentioned it as a war objective.

\section{The roots of the SDSC}

Gradually, in the 1960s, the generation of Australian ideas on international security and defence strategy became more open to outside influences. There were the out-and-out critics active in the universities and the newspapers. They did not achieve much influence. And there were the critics who stood on respected ground, and here I refer particularly to Tom Millar, Alan Watt, Bruce Miller and Hedley Bull. They all were given an audience by those on high in the government and in the Departments

2 Peter Edwards, Arthur Tange: Last of the Mandarins, Allen \& Unwin, Sydney, 2006, Chapter 6. 
of External Affairs and Defence. They were not given an easy ride. Because Tom and Alan had served in the army and the foreign service respectively, there were questions of ego to be faced on both sides in making the dialogue work. Hedley, who had made his reputation on the other side of the world in a field most Australians knew nothing of - arms controldid not face personal hostility, but he still had to get his message across, which was in part to stand up to the great powers, especially our allies, and in part to view nuclear weapons as a global problem that required a global solution. He exerted a useful influence in persuading key people in the Department of External (and then Foreign) Affairs to develop a positive approach to the Nuclear Non-Proliferation Treaty. Bruce's connections were stronger on the side of the Department of External Affairs than that of the Department of Defence, but he used them skilfully and built up the Third Monday Group, which flourished from the late 1960s through to around 1973, bringing together government department heads and deputy heads with relevant Australian National University specialists once a month. The growth of tensions over the Vietnam War led to this arrangement breaking down, and it ceased to function in the dying days of the McMahon Government.

During the late 1960s, the newly founded centre was taking its first tentative steps forward in offering advice, public and private, on national and international security issues. We were lucky in that Tom, Hedley and Bruce all had experience of working at and with the International Institute for Strategic Studies in London. That experience gave them several advantages: a broader approach to international security than just that of a national perspective; experience of working as academics with members of the government community, both civil and military; personal networks of expert people around the world, both in government and outside; standards in assessing ideas and writing; and knowledge of how to fund such an operation without allowing the resulting work to be skewed by the funders. All this knowledge and experience helped the Strategic \& Defence Studies Centre get off to a good start. It was an early 'golden era' both for the field internationally and here in Canberra. These elements remain very important for the Centre's future standing and the quality of its work. 


\section{Necessary ingredients for strategic studies}

Let me now review what I think are the necessary ingredients for the flourishing of strategic thought today. First are the people: expert, accomplished or promising to be so; second, a breadth of expertise from the military field through social politics, economics and international relations to peace studies; third, a supportive institution such as ANU to have as a base; and fourth, national and international perspectives in its work.

\section{People to shape the dialogue}

Probably the most important element in shaping the dialogue in the future will be the quality of the people who are conducting it. And probably the most significant factor to look for and nurture here is intellectual quality, especially the ability to think outside the box and to resist being co-opted by a dialogue partner who is hierarchically organised. We have been lucky to date with our range of contributors, beginning in the 1970s with two young men in their 20s, Des Ball and Ross Babbage. Many more have come on since then, from a wider range of home institutions and agencies, including the armed services.

They do not all need to be offered a tenure track position because many of them will be needed in their own agencies where they worked before coming to the Centre. The Centre's continuing semi-permanent and permanent staff will be relatively small. They should come in at a range of points in early and mid-career to keep things on the boil and crossfertilise from different vantage points. The three-person team we had in Des Ball, Ross Babbage and Jol Langtry is a good case in point. All the staff members need to be not only very bright but also producers. They need not only to write easily but also to be good conference and discussion group members. They not only need to make their own contribution but also allow others to influence them. They need to know how to develop and sell an idea, but not to oversell it.

\section{Breadth of experience required}

Because the range of problems that needs to be tackled in strategic policy analysis is so broad, we need people from a variety of disciplines and work areas, not to mention both genders. I have not mentioned science and 
engineering as necessary inputs yet, because it can be very difficult to find the right people from those quarters to take part in the work of a larger team that is focused on wider objectives and composed largely of others whose backgrounds lie in political science, international relations, geography and history. Nonetheless, we have to accept the challenges and bring more technological expertise into the debate.

As someone who has been mentored by Michael Howard and Basil Liddell Hart, I cannot omit mention of the importance of history as a major area of expertise in the field of strategic studies. Hew Strachan has already made reference to this point, so I shall not labour it too heavily. However, history is important for several reasons in the making of good policies for future use. History offers a scale of known facts against which the consequences of new policies can be assessed. Knowledge of history enables clouds of illusion to be dispersed. History brings a spotlight to shine on the personal factors that can do so much to make or mar an intense, dangerous activity such as a war or a conflict. History also reveals the recurring but deceptive traps into which government leaders and force commanders can fall so easily, such as overoptimism, technological limitations and imperfections, the role of public opinion and the limitations on what both civil populations and armed forces are willing to bear. The Centre has been well served by David Horner, Joan Beaumont and many other people with historical expertise.

Strategic policy is, in the final analysis, a political business. It therefore needs the contribution of political wisdom if it is to have a sound purpose and remain within the confines of available resources. From where do we acquire political wisdom? Journalists are one obvious source. Another is rising members of parliament. A third is political staffers. These are all bright people who have to think about defence and foreign policy issues and commit themselves to opinions on them. Many of those who take part in this political discussion of security policy are very aware of the limits of their knowledge. They need help, and this can be another important contribution that the Centre can make and has done in the past. Politicians are extremely busy people with all kinds of pressures on their time and energy. Therefore any assistance offered must be well focused and address their needs without wasting any of their precious time.

It is important to balance political connections. It would be a big mistake for the Centre to gain the reputation of being the think tank of one party or another. Fortunately, there has not been a fundamental division on 
security policy issues between the major parties for quite some time, and it is possible to work with both sides without becoming compromised. Another set of opportunities lies in speaking publicly or semi-publicly at party conferences and lesser gatherings and appearing before relevant parliamentary committees.

A related group of people that the Centre needs to have a good relationship with is the public service-a huge repository of relevant knowledge and expertise, not to mention thinking and debating capacity. Without some working connection with people who work in Defence, Foreign Affairs, Prime Minister's, Treasury and some other departments of state, the external debate in research institutes might well be duplicating or even trailing behind the debate taking place within the halls of government. Not everyone in the government's employ will want to work with outsiders. There are obvious risks in such connections for both sides. But quite a lot are keen to be engaged, if properly asked, and they add a huge amount to academic capacity because they have substantial resources at their command, they know what politicians think, and they have great connections. My own early visits to Moscow and Beijing were greatly facilitated by Paul Dibb, who provided me with access to an array of his best contacts in those capitals of enigma. Later, when I was at the International Institute for Strategic Studies (IISS), I found that a high proportion of our best contributions in debate, in conferences and in advice generally came from the civil service of the United Kingdom, other European North Atlantic Treaty Organization (NATO) states, the United States and Canada.

Another important resource is the diplomatic corps in whatever capital city one happens to be working. As in dealing with the public service, care in selection of contacts is necessary, and you should not believe everything you hear. But in terms of getting the best value from dollars spent on international travel, good diplomatic contacts are one of the best aids that one could have. That means reciprocal care of them on one's home base also.

Although we were deeply involved in the Cold War in the 1970s, we were able to have a relatively friendly relationship with the staff of the Soviet Embassy. There is no doubt that at times they became bored with having to propound their official line on everything. Sometimes they might relax a little and let me see what was really on their minds, whether it was on arms control policies or on social conditions at home. There were risks in 
this semi-public relationship, of course. After one conference, which had been attended by a mid-level Soviet diplomat, Peter Samuel, a well-known journalist, published a newspaper article headlined 'The SDSC-Where ASIO meets the KGB'. Samuel had recognised a senior ASIO member in the audience as well as the Russian. That afternoon, after the paper had appeared, the Russian came urgently into my office, saying: 'Bob! Bob! I am not KGB!' I could have said: 'No, Yuri, you are GRU!' but I forbore. I was glad that the Soviet Military Intelligence Service, the GRU, thought we were sufficiently relevant to be worth keeping an eye on.

Finally, let me mention another important group that has a major contribution to make to strategic studies: the armed services. I would not have said this so confidently 40 years ago, but times have changed. The armed services themselves see much more to be gained from education, debate and post-graduate qualifications than in the 1960s when I was a member of the Australian Army. The idea of the Joint Service Staff College, with which several of us became involved in the 1970s, has blossomed into the Australian Command and Staff College, which has its own highly qualified faculty as well as a considerable body of students drawn from around the world.

Given the nature of recent major wars, from Vietnam to Afghanistan, it is very important that we know more about what is happening at the coalface. What works, and what does not? The people who are actually out there, boots on the ground, exposed to death and injury by improvised explosive devices (IEDs), mines, sniper shots and assassin groups, are best equipped to give a verdict. Then their judgements need to be picked up, brought home and considered. I applaud the work that my former doctoral students John Nagl, Carter Malkasian and Daniel Marston have done and continue to do in this regard, but we need more of them as well as from them. This kind of warfare, which is wider than 'counter-insurgency', looks as though it will be with us for a long time. We need to keep lifting the standard of our effectiveness to bring conflict under control and keep it moving towards an end that we will be happy to accept.

\section{A strong institutional base}

If the Centre is to continue to flourish, it needs a strong resource base to support its work and to give it the strength to exert an influence. In the 1970s it was not at all clear that the resource base would be adequate, but thanks to the good efforts of Des Ball and Paul Dibb as Centre heads, the 
necessary resources were found. Over the past decade, the resource base provided by the university has grown. Now under Brendan Taylor, the Centre is at a level of strength that has not been exceeded previously. The level of support offered to strategic studies has been increased with the addition of the National Security College and the sharper focus given to the work of the Coral Bell School of Asia Pacific Affairs.

Of course nothing should be taken for granted in the turbulence of university politics, but given the widely accepted importance of the subject and the many ways in which the world is getting into increasing difficulty, I am tempted to say that the resource base will be adequate provided that the Centre continues to produce good work. Having worked for several years outside the university framework, let me say that this is a great advantage. Supplementation by grant funding and contract work in teaching and supervision can be added to the mix, provided it is done without compromising the Centre's independence, both actual and perceived.

\section{National and international cooperation}

However, let us not think too much in a Canberra mode. The work of the Centre is, of its very nature, international and interdisciplinary. Fortunately, its influence is enhanced through the presence in Canberra of the Australian Strategic Policy Institute, the Australian Command and Staff College and the Australian Defence Force Academy. Then there is the wider layer of institutions that work in our field in nearly every Australian state. Here I think particularly of the Lowy Institute in Sydney, the Australian Institute of International Affairs nationwide and the Perthbased think tank Future Directions International. There is a lot of good work being done right around Australia, and thanks to the Internet it is being made available to all those who are interested and able to tunnel their way through the various websites involved. However, all this work needs to be brought together, assessed and the best of it disseminated more widely. There is a role for a national leadership team!

Looking further out across our national borders, we have a good tradition of regional cooperation with the principal research institutions of SouthEast Asia, South Asia and East Asia. They offer a vital range of inputs, and they are also a discriminating group of assessors of work done in Australia. The Centre needs to look to its reputation among this group, which embraces both first- and second-track connections. 
On the other side of the Pacific, we see the strongest national powerhouse of ideas in our field in the United States. We have strong links with US research institutes and universities. For decades we have gone there and worked our way around. Now it is good to see them come to us, as the RAND Corporation has done recently. The United States is in itself going to be a particularly interesting place to observe and analyse in the era of President Donald Trump. We know from the recent debate that a substantial slice of the American electorate is not willing to support 'free-riding' allies. Wars that result in substantial human casualties are not supported by public opinion unless the stakes are very high. The US armed services (and their personnel) remain very technologically oriented. How does this equip them for gaining the friendship and cooperation of largely pre-information technology people who are apprehensive about the consequences if they and their societies ascend the technological ladder? There are many problems of this kind and uncertainties regarding the future policies and capabilities of our major ally for us to think about.

Globally, let us not forget the capabilities and connections of the International Institute for Strategic Studies. Its size, scope and breadth of its membership are unique. It was a dominant part of my life for 20 years, and it is pleasing to see Tim Huxley of its directing staff here today. I hope the IISS and the SDSC will continue to work fruitfully together in coming decades.

\section{New conditions of the 21st century}

Moving from the mid-20th to the early 21 st century, there are several relevant differences that I should note.

First, until the British referendum of 2016, international boundaries were becoming less significant than they were in the mid-20th century. Cooperation in strategic thinking between nations, groups of nations (especially alliances) and globally has become a much more common and natural process. It is hard now to imagine millions of young men in Europe reporting to mobilisation depots on a few days' notice from their national capitals. Western powers simply could not do it, although a few non-Western states probably could. We can still blow each other to pieces with nuclear weapons, and subnational groups may be able in future to do so. We live in a very different context of public opinion from that of the early and mid-20th century. Hatred still exists between nations, but it is 
more confined than it used to be and most governments find it a problem rather than an advantage. However, conversely, international flows of refugees are strengthening the significance of national boundaries. How do we keep them effective in this sense without encouraging hostilities?

A second difference, reinforcing the power of the first, is the Internet and the huge array of devices that work through it, ranging from the personal computer and iPad to the smart phone and 'social networks'. These are major new factors with strategic relevance. They threaten the power of authoritarian and weak governments. They enable insignificant individuals and groups to become significant actors. They threaten to undermine traditional authority structures, including political parties, government departments, armed services and police. They will need to be taken into account as never before. As the use of the Internet has grown, so has the power of the hacker and the spy. I shall not go into further detail on these forms of warfare because they are already under attention by the cyber-security community. They are becoming more important as we come to rely more heavily on information technology, and we must take them more into our own thinking.

On looking forward into the coming century, it is obvious from events in Africa and the Middle East that we need to focus more closely on a third set of issues-namely, the 'quality of government'. This is one of the key elements in what we have called over the past 60 years 'counterinsurgency'. Of course counter-insurgency also requires specialised military capabilities, including the ability of counter-insurgent forces, especially when they come from afar, to relate to and become friends with the people they are trying to help. Also the counter-insurgents need in-depth knowledge of the country or region in which they are operating.

Fourth, we can expect to see less of major conventional warfare than in the era of the world wars, but I do not expect to see it disappear, except possibly among the major powers. At that level it is simply too destructive an option to take up against each other, although that does not mean that they will not ever use it. Therefore, conventional warfare will remain an important element of strategic studies.

Fifth, as the use of the seas grows in intensity, there are going to be more maritime disputes covering such issues as national sovereignty, Law of the Sea, control of refugees and access to minerals. Similarly, we can expect a growth of air-related problems as ground-launched missiles become 
more readily available, terrorists work out more ingenious ways for taking control of aircraft for their own purposes, and aircraft can be coupled with information technology to give a new dimension to espionage.

We are all aware of the increased salience of economic factors in national and international security. We will need to pay greater heed to the quality of national government economic management in states of interest to us, the effects of uneven distribution of resources within societies, the interdependence of states for access to critical materials-from foodstuffs to fuels - and the management of the huge costs of defence and security policy.

I should mention in passing the issues of the use of space for travel, communications and exploration. At present, we have a network of treaties and agreements that make it difficult for one state to threaten another from space, but those agreements can always be infringed. We are also sending off a series of probes and broadcasts designed to attract the attention of anyone 'out there'. It seems to be assumed by the scientists responsible for these missions that the creatures whose attention may be drawn to us will be pleasant and well behaved when they come to inspect us. We need to probe that question a little more deeply too!

\section{Conclusion}

While I have focused these remarks on the Strategic \& Defence Studies Centre, I think they have application to research institutes in the field of strategic studies the world over. And that is important-we have a tough set of global problems to deal with. The set of challenges that I laid out at the beginning of this chapter will have to be dealt with on a global basis rather than just a national or even a regional one. We need to assemble a widely composed team of national and international institutions to grapple with and hopefully solve them. I think Australia is ready to play a part in meeting this challenge, and doubtless others are too. Let us all get working and keep the sunlight pouring down to help us solve formidable problems. Another dark age, at the world's current level of population and resource consumption, would be very nasty indeed! 
This text is taken from New Directions in Strategic Thinking 2.0:

ANU Strategic \& Defence Studies Centre's Golden Anniversary

Conference Proceedings, edited by Dr Russell W. Glenn, published 2018 by ANU Press, The Australian National University, Canberra, Australia. 